\title{
OVERCOMING TAQLID IN MUSLIM INSTITUTIONS OF LEARNING
}

\author{
Abdul Karim Abdullah*
}

\begin{abstract}
The emergence of taqlid or indiscriminate imitation of the work of former scholars by later scholars was a major turning point in Islamic history. It created two classes of scholars, those who referred to the primary sources of the Shariah (the early scholars), and those that did not (the later scholars). As a result of the expectation to follow and build on the work of the early scholars, the Qur'an and Sunnah attained the status of "remote" sources, at least as far as the later scholars were concerned. The works of the early scholars, by contrast, were brought forward and came to be treated, for all practical purposes, as "primary sources." The distancing of the later Muslims from the Qur'an was reflected in how Muslims came to relate to the sacred text. Scholars began to look outside of the Qur'an itself for the meaning of the Qur'an, more specifically in the commentaries of their predecessors. Other Muslims were advised to focus on recitation and leave the interpretation of the sacred text to scholars. As it was the Qur'an that provided the impetus to the rise of the Islamic civilisation in the first place, civilisational renewal will require a re-engagement with the Qur'an, by scholars as well as the wider Muslim community. Reopening access the Qur'an will have to begin with a reappraisal of learning methodologies currently in use. This will require first and foremost overcoming taqlid.
\end{abstract}

Keywords: taqlid; education; civilisation; reform; knowledge

\section{Introduction}

Existence manifests itself in the form of cycles. Civilisations arise, grow and decline. The Islamic civilisation was no exception. Like other civilisations, it experienced both growth and decline. After declining, it emerged again in different parts of the world. ${ }^{1}$

There is no doubt that the key factor in the rise of the Islamic civilisation was the enlightenment conveyed by the Qur'an, delivered and implemented by the last prophet, Muhammad, (pbuh). ${ }^{2}$ "No other sacred scripture has ever had a similarly immediate impact upon the lives of the people who first heard its message and, through them and the generations that followed them, on the entire course of civilisation." 3

Success requires, among other things, knowledge of the difference between right and wrong. Man left to his own devices is unable to answer the deepest questions, those relating to good and evil, right and wrong, or noble and base: "on 
its own, the human mind is incapable of understanding the complete objective truth about, and the higher purposes of, the human experience." ${ }^{\prime 4}$

The rise of empirical science, while contributing to economic progress and development, has distanced man from revealed knowledge. The insight provided by divine revelation is obtained as much by intuition as by intellection, as divine revelation touches on themes beyond the purview of empirical science. Relying as it does exclusively on sensory perception, empirical science is unable to provide credible answers to deeper questions, in particular questions regarding good and evil.

Empirical science is ill equipped to enlighten man about ethics, to make statements of a normative character. Such science can only describe, but not prescribe. It can only answer questions about "what is" but not questions about "what ought to be." The application of the modern scientific method experimentation and analysis - can only identify and describe specific cause and effect relationships in the physical universe. These relationships are summed up in the form of generalisations of varying degrees of precision, depending on the subject, known as "scientific laws." Empirical science, due to its dependence on sensory perception, is unable to comment on any aspect of - or even to acknowledge - metaphysical reality.

Human reason without the assistance of divine revelation within the humanities similarly has its limitations. It is limited in its ability to grasp the deepest, transcendental truth. Once again, the inadequacy of merely human effort to answer the deepest questions obliges man to turn to knowledge obtained from a higher source. This knowledge comes to man in the form of what is known as divine revelation.

The latter provides man with a bridge to the "beyond" or what the Qur'an refers to as the "unseen" (al-ghayb), the realm of existence inaccessible by means of mere sense perception. Revealed knowledge is the guiding light received by man from his Creator. It enables man to live in accordance with the divine will, to conduct himself with justice and to fulfill his destiny.

Divine revelation provides humanity with guidance in the form of universal principles. The fact that these principles have been revealed during particular historical periods, or in response to specific historical developments, does not diminish the universality or applicability of those principles at other times. ${ }^{5}$

The universality of the ethical principles conveyed in the Qur' an, and illustrated in the practices (sunnah) of the prophet (pbuh), makes possible their application at different times and in a variety of different contexts. However, if universal principles are confused with practices that may have been appropriate for a particular historical period but may not be suitable for another one, difficulties may arise. ${ }^{6}$ Expecting past - historically bound - interpretations to provide viable 
responses to contemporary problems is problematic, as early scholars "could have no conception of the necessities of the twenty-first century Muslims."

\section{Emergence of taqlid}

Taqlid has been defined as "indiscriminate imitation of others." Taqlid in the sense in which this term is used here obliged scholars to defer to the works of their predecessors, rather than refer directly to the primary sources of the Shariah. ${ }^{8}$ It was expected that a Muslim "should follow one or the other of the established schools of thought and abandon his judgment in favour of interpretations of the earlier centuries." Intellectual activity was reduced to making commentaries on commentaries.

With the so-called closure of the door of ijtihad, the 'ulama resorted less and less to the sources of Shariah finding solutions to problems. Instead of addressing social issues and attempting new solutions the 'ulama of the later ages ... occupied themselves mainly with elaboration ... of the works of their predecessors. ${ }^{10}$

Taqlid may be practiced by a layman or a scholar. The common factor in both types of taqlid is that an appeal to authority takes precedence over reasoning based on evidence as the criterion for differentiating sound opinion from an unsound one. ${ }^{11}$

No human activity is immune from the practice of taqlid. It may be found in jurisprudence (usul al-figh), interpretation (tafsir), or in other pursuits. As ijtihad (juristic reasoning) presupposes interpretation, it follows that the results of jurisprudence depend in a decisive way on the methodology of interpretation applied in the reading of sacred text.

The institutionalisation of taqlid took place in stages. It narrowed the scope and diversity of Muslim intellectual inquiry. ${ }^{12}$

At first, ijtihad was prohibited. Then in the fifth and sixth centuries, scholars were restricted to tarjih, or giving preference to the opinion of one imam or another on questions of figh. But then tarjih was prohibited and scholars were restricted to choosing between rulings within a single madhhab. ${ }^{13}$

It appears that the practice of confining themselves to elaborating the works of their predecessors, without accessing the primary sources of the Shariah directly, distanced the later scholars from the first and foremost source of the Shariah, the Qur'an. This was a consequence of the adoption of a specific hermeneutical principle. The principle in question 
required that participants in a school tradition ... preserve loyalty to the tradition by taking into account the interpretative achievement of older masters ... law had to be justifiable by reference to the continuity and established identity of the school. Muslim jurists were not, as individuals, in solitary and direct confrontation with revelation: they found their way back to the meaning of revelation through tradition. ${ }^{14}$

By obliging later scholars to access the primary sources of the Shariah through the eyes of former scholars, the practice of taqlid altered the relationship between the believer and the sacred text. The believer - whether scholar or expert - no longer enjoyed, as the early generations of Muslims did, direct access to the sacred text, but was expected to refer, and indeed to defer to the views of renowned scholars. ${ }^{15}$

No doubt, taqlid was introduced with good intentions. After all, even children learn first by imitating those older than themselves. Thus, some forms of taqlidsuch as that applied in religious practices or ibadat - are not only acceptable but even necessary, especially in the case of the vast majority of ordinary Muslims. Yet even a child has to grow up at some point, and stop depending on his or her parents. The fact that a young person no longer needs to "imitate" his or her more knowledgeable peers is a sign of maturity. Such a person knows the reasons for his or her actions and is also broadly aware of their consequences. Such a person thereby becomes responsible for his or her actions.

Taqlid was introduced in part as an answer to the growing plurality of opinions and a desire to put an end to the proliferation of debates and disagreements about what precisely constitutes Islamic law. ${ }^{16}$ There may have been a perceived need to codify the law and introduce a degree of uniformity into it and in that way to make it easier to administer it, especially by less knowledgeable judges. ${ }^{17}$

However, taqlid is problematic for several reasons. First, simply following without reflection - the religion of one's forefathers is censured in the Qur'an in several verses, namely in 5:104-5, 17:36, 21:52-54, and 43:22-24. Moreover, the uncritical acceptance of the views of former scholars departed from the tradition of ikhtilaf (differences of opinion) that characterised the early generations of Muslims.

No researcher or scholar has ever found a valid text from either the Qur'an or the hadith, or even an argument based on pure reason, to support Islam's approval of taqlid, for the very idea is alien to Islam's view of humanity. The teachings of Islam clearly state that all assertions must be supported by either verifiable evidence or proof ... If such conditions cannot be met the assertion is to be rejected. ${ }^{18}$ 
Despite worthy efforts by renowned institutions of higher learning such as the University of Al-Azhar, going back for decades if not longer, taqlid continues to be practiced in several parts of the world. In India, for example, "Hanafi jurists have long argued $\neg$ as did many of those belonging to the other schools of Sunni law - that all continuing legal reflection ought to take place within the parameters of the school, in strict conformity to the methodological principles articulated and agreed upon by the earlier masters." 19

The practice of taqlid also persists in some institutions in Pakistan. For example, "The ulama of Deoband not only adhered to the Hanafi school, but also insisted that any deviation from taqlid was a serious matter of concern and must be confronted because it was no less than bida't (innovation). To the Deobandis, the gates of ijtihad were firmly closed." 20

The adoption of taqlid was justified by the claim that the earlier generations of Muslims had a better understanding of Islam than the later generations. The better understanding was due to the closer proximity of the earlier generations to the prophet (pbuh). This resulted in the perception that "the sayings and opinions of the salaf (predecessors) are nothing short of sacred. This is especially true in regard to the understanding, ijtihad, and interpretations of the salaf some of which have been elevated by the traditionalists to the status of revelation itself."21

One result is that "in our traditional institutions" the authority of past scholars "is elevated to the level of the prophet (pbuh) and sometimes even above it." 22 Another result is that "The word of the Imam of the Madhhab is occasionally followed in defiance of the word of Allah (s.w.t). ${ }^{{ }^{23}}$

In response to the restrictions placed on independent inquiry by the need to defer to the views of former scholars, a number of contemporary scholars have called for "reform and renewal in Islamic thought." ${ }^{24}$ In particular, there have been calls "to free the discipline from the dominance of past scholars." ${ }^{25}$ What is required is to rekindle the "tradition of reason and intellectual inquiry, which will in turn lead to a culture of learning among the Muslims." ${ }^{.26}$

Islam must not be ossified and fossilized by blind imitation of traditional thought and opinion. Rigid obscurantism, exclusively literalist doctrines and atavistic doctrines of a past ideal, prevents Islam from being a religion for all time as intended by Allah. We must be open to the prospect of reform (islah) and renewal (tajdid). ${ }^{27}$

The key to the renewal of the Islamic civilisation lies in overcoming taqlid. ${ }^{28}$ It needs to be recalled that, "differences of opinion are the basis of all progress in human thinking and, therefore, a most potent factor in man's acquisition of knowledge. ${ }^{29}$ 


\section{Consequences of taqlid}

The adoption of taqlid had a number of adverse consequences. First, it contributed to a decline of critical reason. "The persistent decline of critical reason among Muslims is due partly to the notion that the exercise of personal judgment and ijtihad ceased with the epoch-making works of the legists and imams of the past." ${ }^{11}$

A decline of critical reason carries a number of risks. As "tradition" evolves, new ideas are added to it in the form of scholarly contributions. Yet there is no guarantee that all such contributions will faithfully reflect, and be consistent with the fundamental teaching of Islam as recorded and transmitted in the Qur'an.

The application of critical reason is also vital to the well being of the individual. It is unlikely that a person could attain to faith without the use of the intellect, required in acquiring and applying knowledge, whether revealed or otherwise. The Qur'an consistently exhorts people to use their intellect ('aql). It is likewise unlikely that, after acquiring it, a believer would be able to maintain his or her faith without the continued use of his or her intelligence.

The view that a commitment to faith somehow requires a person to abandon the use of his reason may be a result of a misunderstanding of attaining religious consciousness. A commitment to "faith" properly understood does not require the believer to abdicate the use of his reason.

On the contrary, a commitment to "faith" requires the engagement of the intellect not only at a basic (empirical) level but also at a higher (intuitive) level. At the basic level, sense perception alerts the believer to the visible "signs" (ayat) of God. The intellect in turn draws the necessary conclusions from this perception. At the higher (intuitive) level, the intellect or more precisely what the Qur'an calls the "heart," enables the believer to grasp the reality that lies beyond the totality of what can be accessed by mere sense perception.

A major consequence of the adoption of taqlid was that "The creative impulse of Islamic thought suffered setbacks as a result." ${ }^{32}$ In this way, "the door to independent legal thought was shut and then barred." ${ }^{\prime 3}$ Later generations of scholars were expected to follow the views of the former generations of scholars. ${ }^{34}$ Taqlid also contributed to the rise of fatalism (jabr):

It became increasingly common for political leaders to seek justification for their mistakes and aberrations by citing this doctrine [of fatalism]. Quite simply, if their actions and decisions had been determined beforehand, they could not be held accountable for them, and their subjects could have no justification for rising in revolt against them. In effect, it gave them a carte blanche to rule the ummah as they saw fit. As it was to their advantage, many rulers and court-supported scholars 
favoured it despite the opposition of the traditional ulama ... Taqlid thus cleared the way for fatalism, which in turn prepared the ground for tyranny, injustice and despotism. ${ }^{35}$

Taqlid also altered the conception of what constitutes knowledge. This alteration resulted in a marginalisation of worldly knowledge and the prioritisation of religious knowledge.

\section{Taqlid and knowledge}

Education enables a person to live well. In a religious context, this means to live in accordance with the will of God. Knowledge enables a person to avoid harm, both to himself as well as to others. It also enables a person to obtain benefits.

Knowledge begins with the emergence of consciousness of the self and of the "other." The "other" in the first instance includes the parents of a newborn, siblings, friends, neighbours, classmates and fellow citizens.

The most important "other" is God. The awareness of God takes both an intellectual and an intuitive form. When a person attains the awareness of ultimate reality - God - that person attains God-consciousness (taqwa). Thus, the highest form of cognition is consciousness of God. The purpose of education is to enable a person to become conscious of God and live accordingly.

Religious knowledge provides guidance on how to conduct oneself. It also provides guidance on how to utilise other kinds of knowledge. Empirical knowledge provides the means of cultivating the earth and obtaining various benefits from it.

The content of religious education is provided by divine revelation. Knowledge of the world (physical universe) is provided by the empirical sciences. The two types of knowledge, utilised together, help man to fulfill his responsibilities as the vicegerent (representative) of God on earth. What is needed is to strike a balance in the pursuit of the two types of knowledge. ${ }^{36}$

Knowledge of revelation is obtained by means of the religious sciences, while empirical knowledge is obtained by scientific experimentation. Religious sciences include Qur'anic exegesis (tafsir), theology (kalam), jurisprudence (usul al-fiqh) and others. Empirical knowledge includes the knowledge of physics, biology, chemistry and other subjects.

The knowledge of revelation is obtained from the "first book" of God, the Qur'an. Empirical knowledge is gained from the "second book" of God, the world of creation. ${ }^{37}$

Both "books" contain the signs (ayat) of God. We are advised to study and reflect on both "books." One challenge we face is how to integrate these two types of knowledge. 
The knowledge of the modern sciences increases our capacity to produce goods and services, but revealed knowledge provides guidance on how to use the knowledge of the modern sciences for good rather than evil purposes.

The dichotomy between religious and modern education arose when the pursuit of religious education was separated from worldly education. Despite the fact that a number of Muslim institutions of learning have made significant strides in overcoming this dualism, the segregation of religious education from modern education persists in some Islamic institutions to this very day.

The growing emphasis on religious education at the expense of (modern) scientific education appears to have been part of a long-term trend. Under the Mughals (1556-1858), for example, "Within madrasa education, the tradition of manqulat (revealed/transmitted knowledge) was consolidated over time at the expense of the tradition of ma "qulat (rational sciences). ${ }^{.38}$ However, this was not always the case: "Interestingly, in the early days of the empire, it was the study of ma "qulat that spread widely." 39

In Pakistan, madrasa education still gives preference to religious knowledge at the expense of other kinds of knowledge. The result is an ineffective educational system, in much need of reform.

The sect-specific Islamic curricula of madrasas without any integration with sciences, arts, humanities etc. segregate it from any other need based educational system followed all over the globe ... ${ }^{40}$ [Thus] ...

Reforms in the educational system of madrasas are needed by including scientific and non-theological subjects in curricula and improving the existing pedagogical practices. ${ }^{41}$

In order to restore the balance in education, the notion of what constitutes knowledge needs to be broadened, to incorporate modern scientific knowledge into the curriculum, in addition to traditional religious knowledge, in all institutions where this has not yet been accomplished. The two kinds of knowledge need to be integrated and pursued together. They complement each other. ${ }^{42}$ Empirical knowledge confirms divinely revealed knowledge: "the Qur'an has encouraged rational argumentation in religious matters, and it has consistently recommended investigation and inquiry into almost all aspects of creation." ${ }^{\prime 43}$

\section{Taqlid and the study of the Qur'an}

Taqlid also impacted the role that the Qur'an was to play in the lives of ordinary Muslims. While the later scholars were advised to follow the earlier scholars, ordinary Muslims in turn were expected to rely on contemporary scholars for 
their understanding of the Qur'an. As a result, ordinary Muslims also became distant from the Qur'an.

In the case of the latter, this "distance" is illustrated by the fact that while not a few Muslims can recite the Qur'an, few actually comprehend what they recite. Students are encouraged to imitate correct pronunciation to perfection by recognised reciters. Little emphasis is placed on the comprehension of the sacred text.

The emphasis on recitation at the expense of comprehension has been justified by the claim that the Qur'an is a "difficult" book that only a few can understand, namely qualified jurists. But there is little support in the sacred text itself for this view. On the contrary, the Qur'an asserts that it is "easy to understand and remember." The statement,

And We have indeed made the Qur'an easy to understand and remember ..."44

is repeated for emphasis in four different verses in one chapter alone. That the Qur'an was not intended only for a "select few" is confirmed by the fact the Qur'an presents itself as "a message to all the worlds."

As a result of the view that the Qur'an is "difficult" to understand, Muslims are generally exhorted to read the sacred text only with the help of a teacher to guide them. ${ }^{45}$ Requiring people to read the Qur' an only when a guide is available, however, does not help to bring the message of the sacred text any closer to the believer.

Focusing on recitation at the expense of comprehension effectively separates reading of the sacred text from its comprehension. The result is recitation without comprehension. "The basic approach to Qur'an studies ... emphasised correct pronunciation and memorization." ${ }^{46}$ This has been identified as problematic by a number of commentators.

It is ironic to note ... that the vast majority of Muslims are wont to rote reading of the Qur'an which is patently vacuous and devoid of thinking. The Qur'an is usually read, committed to memory, and cited for its spiritual merit rather than intellectual stimulation and enrichment. This is evidently not the advice one obtains from the Qur'an itself. ${ }^{47}$

Another observer noted, "our traditional system, for all its virtues, is sharply criticized ... for relying largely on rote learning and parrot fashion repetitions ..." ${ }^{48}$ The result of rote reading is that the message of Islam is poorly understood and presents a "contradictory and confused picture." 49

The relationship between the divine text (the Qur'an) and the student needs to be re-articulated so as to enable the divine text to speak to the believer. 
Many writers are critical of the current stress on parroting entire sections of books without exercising reason or critical thought, as a result of which few students are said to actually properly comprehend what they are taught. Critics see the madrasas as discouraging debate, dialogue and critical reflection, and as treating their students as passive students, thus cultivating a climate of stern authoritarianism. ${ }^{50}$

What is required is a more intellectual approach in education. ${ }^{51}$ More emphasis needs to be given to comprehension of the sacred text than has hitherto been the case. Also, student centered learning should be introduced. Some contemporary institutions of higher learning have already adopted interactive methods of learning:

The method of teaching is through dialogue. The question is put to the student and they are encouraged to find their own solutions. We do not mock them if they err; we simply show them that this suggestion does not work; we help them find the solution. Our method is not the fast food package that is handed to the students without any effort on their part. Rather, it is the carefully prepared banquet, which they work to bring about, and which they greatly enjoy. ${ }^{52}$

A method that requires exertion and effort on the part of students is preferable to a method that only requires passive acceptance of "processed" and readymade "knowledge." The Qur'an encourages thinking and questioning. "Islam ... advises analytical knowledge and understanding that generate insight rather than a purely dogmatic approach." ${ }^{53}$ The Qur'an needs to be presented in a way that makes it "truly comprehensible." 54

This method will need to emphasise comprehension as much as pronunciation. In other words, it will require restoring the balance between recitation and comprehension. The main challenge in Islamic studies is "how to foster a critical approach while maintaining loyal commitment ..." 55 This can be realised by an educational system that is well-grounded in tradition and is able at the same time to foster "independent thought based on a well developed critical ability."

\section{Conclusions and recommendations}

The Islamic civilisation rose to prominence on account of the guidance contained in the Qur'an. This guidance was elaborated and extended to apply into various walks of life by various scholars and other leaders over the centuries. The practice of requiring later scholars as well as students to look for the meaning of the Qur'an primarily if not exclusively in scholarly commentaries, meant that the later Muslims came to obtain guidance from sources other than those which provided guidance to the earliest generations of Muslims. 
The overdependence on commentaries rather than on the direct guidance contained in the Qur'an itself ensured that the later Muslims' understanding of Islam became essentially a derivative understanding.

Thus, renewal will require re-opening access to the primary source of the Islamic civilisation, the Qur'an. Within the institutions of learning, the understanding of knowledge will need to be broadened, to include comprehension of the text of the Qur'an in addition to learning how to recite it.

The conception of knowledge will likewise need to be broadened to include knowledge of the modern sciences. This will require not only a review of the curriculum or the subjects studied, but also of the methods of teaching used. Teaching needs to be interactive rather than a one-way process characteristic of "teacher centred learning," where the teacher is a "sage on the stage" than a "guide on the side." Taqlid will have to give way to a greater utilisation of the intellect. Reliance on the work of past scholars needs to be reduced.

- Taqlid needs to be overcome and the reliance on the works of past scholars needs to be reduced. Reliance on rote learning should also be reduced and critical and inquisitive thinking should be encouraged.

- A balance in the pursuit of modern knowledge and religious knowledge needs to be re-established. The duality between them should give way to the unification of religious and modern forms of knowledge.

- A balance between pronunciation and comprehension in the teaching of the Qur'an needs to be restored.

- It is recommended to introduce student centred learning. Students should be expected to work with minimal supervision by the teacher and make presentations of their research in class.

\section{Notes}

* Abdul Karim Abdullah (Leslie Terebessy), Assistant Fellow at IAIS, earned his MA in political philosophy from the University of Toronto, Canada (1999) and a MEd (1986) from the University of Toronto's Ontario Institute for Studies in Education (OISE). A former lecturer, editor, writer and coordinator of the English programme at University Sains Islam Malaysia (USIM), his current projects involve research into the current financial crisis, critical thinking in Muslim societies, and Islamic Finance. He has edited Islamic Studies at World Institutions of Higher Learning (Kuala Lumpur: USIM 2004). He can be contacted at abdulkarim@iais.org.my.

1. When the Abbasid caliphate was destroyed by the Mongols in 1259, it was eventually replaced by the Mughal civilisation, the Safavid civilisation, and the Ottoman civilisation.

2. The word "knowledge" ( $\mathrm{ilm}$ ) is mentioned in the Qur'an more than 700 times 
in 87 different forms. The Institute of Islamic Knowledge, accessed online on 5 September 2014, <http://al-quraan.org/about_us.html>

3. Asad, Muhammad, The Message of the Qur 'an, Dar al-Andalus, Gibraltar, 1980, p. i.

4. AbuSulayman, AbdulHamid, Crisis in the Muslim Mind, The International Institute of Islamic Thought, Herndon, USA, 1993, p. 68, accessed online on 26 March 2014, <http://deenrc.files.wordpress.com/2008/03/crisis-in-the-muslimmind-by-abdulhamid-abusulayman.pdf $>$

5. One account of modern efforts to respond to the rigidity in usul al-fiqh (Islamic jurisprudence) caused by taqlid may be found in David Johnston, "A turn in the epistemology and hermeneutics of twentieth century usul al-fiqh," Islamic Law and Society, Vol. 11, No. 2, Brill, 2004, pp. 233-282; accessed online on 27 Aug. 2014, <http://www.jstor.org/stable/3399305>

6. Al "Alwani, Taha J. "Taqlid and the stagnation of the Muslim mind," The American Journal of Islamic Social Sciences, Vol. 8. No. 3, 1991, pp. 513524, p. 522, accessed online on 5 September 2014; <http://i-epistemology. net/attachments/393_V8N3\%20December\%2091\%20-\%20TJ\%20A1\%20 Alwani\%20-\%20Taqlid\%20and\%20Stagnation.pdf $>$

7. Kamali, Mohammad Hashim "Reading the Signs: A Qur'anic Perspective on Thinking," Islam and Science, Volume 4, Winter 2006, Number 2, p. 161.

8. Nyazee, Imran Ahsan Khan, Theories of Islamic Law: The Methodology of Ijtihad, Islamic Book Trust, Kuala Lumpur, 2002, p. 10.

9. Kamali, Mohammad Hashim, "Reading the Signs: A Qur'anic Perspective on Thinking," p. 161.

10. Kamali, Mohammad Hashim, "Methodological Issues in Islamic Jurisprudence," Arab Law Quarterly, Vol. 11, No. 1, Brill, 1996, pp. 3-33, p. 6; accessed online on 27 Aug. 2014, <http://www.jstor.org/stable/3381731>

11. What is at times overlooked, however, is that even an appeal to authority, whether divine or scholarly, requires the use of language, and with language a method of structuring it. The methodology of structuring statements (syntax or grammar) in turn presupposes a distinction between meaningful and meaningless statements. In all statements, logic or lack of it, plays a significant role. Credible statements require the use of valid (logical) inferences. When inferences are made in an illogical way, conclusions may become unreliable. For example, a credible inference should be free of contradictions. A statement cannot be true and false at the same time. Where contradictions emerge, one of the statements becomes untenable. Sufficient scholarly effort thus also needs to be directed to the resolution of contradictions and inconsistencies, whether apparent or real.

What also tends to be overlooked is that the human intellect ('aql) becomes active not merely when one applies the fourth methodology of arriving at a ruling of the Shariah, known as ijtihad or juristic effort. The human intellect needs to be applied at every stage of learning or analysis, beginning with the Qur'an. One cannot simply refer to the Qur'an without utilising the human intellect in one way or another. One cannot even recite or read the Qur'an without applying the intellect to some degree.

12. Halstead, J. M. "An Islamic concept of education," Comparative Education, Vol. 40, No. 4, Special Issue (29): Philosophy, Education and Comparative Education 
(Nov., 2004), Taylor and Francis Group, pp. 517-529, p. 526, accessed online on 23 August 2014, <http://www.jstor.org/stable/4134624>

13. Kamali, Mohammad Hashim "Methodological Issues in Islamic Jurisprudence," p. 6.

14. Calder, Norman, Joseph A. Kéchichian, Farhat J. Ziadeh, Abdulaziz Sachedina, Jocelyn Hendrickson, Ann Elizabeth Mayer and Intisar A. Rabb, "Law," Oxford Encyclopedia of the Islamic World, Oxford Islamic Studies Online, accessed on 5 Jan, 2015. <http://www.oxfordislamicstudies.com/article/opr/t236/e0473>

15. Bayat, Zubair Ismail, The Concept of Taqlid or Ittiba 'in Islamic Law, Dissertation submitted for Master of Arts degree, May 1995, Rand Afrikaans University, pp. 45, 65, 13, 48, 68 accessed online on 8 Jan. 2015; <https:/ujdigispace.uj.ac.za/ bitstream/handle/10210/12889/bayat_zubair_i_1995_master\%20of\%20arts\%20 in $\% 20$ islamic $\% 20$ studies.pdf? sequence $=1 \& \overline{\text { is }} \overline{\text { Allowed }}=\mathrm{y}>$

16. Abdelaal Mohamed A. "Taqlid v. Ijtihad: The Rise of Taqlid as the Secondary Judicial Approach in Islamic Jurisprudence," The Journal of Jurisprudence, HeinOnline, 2012, pp. 171 - 172, accessed online on 12 Jan. 2015; <http://www. jurisprudence.com.au/juris14/abdelaal.pdf>

17. Fadel Mohammad, "The Social Logic of Taqlid and the Rise of the Mukhatasar," Islamic Law and Society, E. J. Brill, Leiden, 1996, pp. 193 - 233.

18. Al 'Alwani, Taha J. "Taqlid and the stagnation of the Muslim mind," p. 516.

19. Zaman, Muhammad Qasim, Ashraf 'Ali Thanawi, Islam in Modern South Asia, Oneworld, Oxford, 2007, p. 59, accessed online on 6 Jan. 2015; http://www. wisdomfort.com/books/WF_English_Books/History_Biographies/ENG_History_ Biographies 003 MawlanaĀshrafAliThanwi MQasimZaman.pdf

20. Riaz, Ali "Madrassah Education in Pre-colonial and Colonial South Asia," Journal of Asian and African Studies, 46(1), 2010, pp. 69-86, p. 81.

21. AbuSulayman, AbdulHamid, Crisis in the Muslim Mind, p. 36.

22. Badawi, M.A. Zaki "Islamic Studies in British Universities: Challenges and Prospects," in Islamic Studies in World Institutions of Higher Learning, Islamic University College of Malaysia, 2004, p. 9.

23. Id., p. 9.

24. While the Arabic islah is typically rendered as "reform," it has a broader meaning. Islah also means "repairing," "rebuilding" or "restoring" something to its original condition. In general islah aims to overcome corruption ( fasad). Thus, the term islah has a distinctively ethical connotation. By contrast, the term tajdid is generally translated as "renewal" or "restoration." Moreover, the term islah is a Qur'anic term, while the expression tajdid is to be found in the prophetic traditions. See Mohamed Abubakr A al-Musleh, Al-Ghazali as an Islamic Reformer (Muslih), A thesis submitted to The University of Birmingham for the degree of Doctor of Philosophy, Department of Theology \& Religion School of Historical Studies The University of Birmingham July 2007, University of Birmingham Research Archive e-theses repository, pp. 31-33, accessed online on 16 April 2014, <http://www.scribd.com/doc/172931962/AL-GHAZĀLĪ-ASAN-ISLAMIC-REFORMER-MUSLIH>

25. Badawi, M.A. Zaki "Islamic Studies in British Universities: Challenges and Prospects," p. 9.

26. Badawi Abdullah, Islam Hadhari: A Model Approach for Development and Progress, p. 169. 
27. Id., p. 39

28. For a critique of taqlid by $19^{\text {th }}$ century scholars, see for example Ahmad Aziz, "Sayyid Ahmad Khan, Jamal al-din al-Afghani and Muslim India," Studia Islamica, No. 13, Maisonneuve \& Larose, 1960, pp. 55-78, accessed online on 17 September 2014, <http://www.jstor.org/stable/1595240?origin=JSTOR-pdf>

29. Asad, Muhammad, The Message of the Qur'an, Dar al-Andalus, Gibraltar, 1980, p. viii.

30. The effect of taqlid on human reason was in a sense the exact opposite of the effect of the European Enlightenment, which elevated human reason to a status higher than was the case during the time of Church dominance.

31. Kamali, Mohammad Hashim "Reading the Signs: A Qur'anic Perspective on Thinking," p. 161.

32. Id, p. 158.

33. Al-"Alwani, Taha Jabir, "The Crisis of Fiqh and the Methodology of Ijtihad," The American Journal of Islamic Social Sciences 8 (1991), p. 332, quoted in Kamali, Mohammad Hashim "Methodological Issues in Islamic Jurisprudence," Arab Law Quarterly, Vol. 11, No. 1, Brill, 1996, pp. 3-33, p. 6; accessed online on 27 Aug. 2014, <http://www.jstor.org/stable/3381731>

34. A number of classical Muslim scholars rejected taqlid. See for example, Montada, Josep Puig, "Reason and Reasoning in Ibn Hazm of Cordova (d. 1064)," Studia Islamica, No. 92, Maisonneuve \& Larose, 2001, pp. 165 -185, p. 170; accessed online on 25 Aug. 2014; <http://www.jstor.org/stable/1596196>

35. Al "Alwani, Taha J. "Taqlid and the stagnation of the Muslim mind," p. 522.

36. Riaz, Ali "Madrassah Education in Pre-colonial and Colonial South Asia," Journal of Asian and African Studies, 46(1), 2010, pp. 69-86, p. 79.

37. Al "Alwani, Taha J. "Taqlid and the stagnation of the Muslim mind," p. 518.

38. Riaz, Ali "Madrassah Education in Pre-colonial and Colonial South Asia," p. 73.

39. Loc. cit.

40. Sial, Abdul Wahid and Syed Waqas Ali Kousar, The structural influence of madrassa education on student effectiveness in Pakistan, does it need to reform? Accessed on 6 August 6, 2014, <http://works.bepress.com/wahid_sial/5/>

41. Loc. cit.

42. This "balance" is sometimes spoken of as the need to integrate both naqli (transmitted) and 'aqli (acquired) knowledge.

43. Kamali, Mohammad Hashim, Freedom of Expression in Islam, Ilmiah Publishers, Kuala Lumpur, 1998, pp. 15 - 16.

44. Qur'an, 54:17, 54:22, 54:32, 54:40.

45. This advice is rooted in the commonly held view among the Muslims that the reader "should not follow his own opinion" about the meaning of the Qur'an, as he is likely to be led astray by his own desires ( $a h w a)$. Bayat, Zubair Ismail, The Concept of Taqlid or Ittiba' in Islamic Law, pp. 17, 81, 83, 85, 87, 96, 98, 102, $104,143$.

46. Kamali, Mohammad Hashim "Reading the Signs: A Qur'anic Perspective on Thinking," p. 164.

47. Id. p. 163.

48. Badawi, M.A. Zaki "Islamic Studies in British Universities: Challenges and Prospects," p. 8. 
49. Loc. cit.

50. Sikand, Yoginder, "Reforming the Indian Madrassas: Contemporary Muslim Voices," p. 136, accessed online on 12 August 2014; <http:// www.apcss.org/Publications/Edited\%20Volumes/ReligiousRadicalism/ PagesfromReligiousRadicalismandSecurityinSouthAsiach6.pdf $>$

51. A number of scholars argued for a more intellectual approach in education. For example, "Muhammad "Abduh (b. 1849-d. 1905) was a chief reformer in the movement of Islamic reform that sprang from Egypt in the late $19^{\text {th }}$ century. He engaged in reform in a time when Muslim society was in a period of stagnation and decline ... His arguments for Islamic reform were firmly grounded within the Islamic discursive tradition that allows for a critical mode of human reasoning (ijtihad), as distinguished from one opposed to unreasoned acceptance of established religious authority (taqlid)." Oxford Bibliographies, accessed online on 22 December 2014;

52. <http://www.oxfordbibliographies.com/view/document/obo-9780195390155/ obo-9780195390155-0001.xml>

53. The institution is the Muslim College in London, UK. Badawi, M.A. Zaki "Islamic Studies in British Universities: Challenges and Prospects," pp. $10-11$.

54. Kamali, Mohammad Hashim "Reading the Signs: A Qur'anic Perspective on Thinking," p. 146.

55. Asad, Muhammad, The Message of the Qur'an, p. iii.

56. Badawi, M.A. Zaki "Islamic Studies in British Universities: Challenges and Prospects," p. 9.

57. Id., p. 11. 